Vol 10, Issue 12, 2017

\title{
A REVIEW ON SCREENING METHODS OF BREAST CANCER, CANCER BIOMARKERS AND PHYTOCONSTITUENTS AGAINST BREAST CANCER
}

\author{
JAYASHREE V*, PRIYANKA S, RESHMA A \\ Department of Pharmacology, School of Pharmaceutical Sciences, Vels University, Pallavaram, Chennai - 600 117, Tamil Nadu, India. \\ Email: mailtovjayashree@gmail.com
}

Received: 30 June 2017, Revised and Accepted: 28 August 2017

\begin{abstract}
A cancer biomarker refers to a substance or process that is used as an indicative the presence of cancer in the body. A biomarker may be a molecule secreted by a tumor or a specific response of the body to the presence of cancer. Biomarkers are utilized in three elementary ways as a diagnostic tool, prognostic tool, and predictive tool. The screening tests employed are clinical and breast exams, mammography, hereditary screening, ultrasound, and attractive reverberation imaging. Biomarkers involved in breast cancer are human epidermal growth factor-2, estrogen receptor, progesterone receptor, Cyclin D1, and Cyclin E. Specific bioactive phytoconstituents used as anticancer include curcumin, genistein, resveratrol, isothiocyanates, silymarin, diallyl sulfisoxazole, lycopene, apigenin, and gingerol. Hence, this review indicates the study of screening methods, various biomarkers in breast cancer and phytoconstituents against breast cancer.
\end{abstract}

Keywords: Cancer biomarker, Breast cancer, Phytoconstituents, Screening methods.

(C) 2017 The Authors. Published by Innovare Academic Sciences Pvt Ltd. This is an open access article under the CC BY license (http://creativecommons. org/licenses/by/4. 0/) DOI: http://dx.doi.org/10.22159/ajpcr.2017.v10i12.21039

\section{INTRODUCTION}

Breast cancer is considered to be one of the common cancer-related cause of death among females. Among women, it caused a major public health concern nearly 1 in 3 cancers diagnosed. It is one of the life-threatening diseases in a woman and they have to face during her lifetime. An increasing incidence of breast cancer reported over the past few decades and leads to the development of new anticancer drugs particularly from plants which showed a large amount of scientific evidence in lowering the risk of cancer [1].

Western European rates five-fold greater than Eastern/Middle Africa toward the incidence of breast cancer. The mortality rates also get differ in Southern/Western African which rates 3 times those of Eastern Asia [2]. By reductions in case fatality, higher incidence in developed countries largely attributable to mammographic screening and also there will be improved adjuvant therapy [3]. To manage the disease, it requires integration of clinical, pathological and biological parameters [4]. The risk stratification was considered to be prognostic histopathological variables which include tumor size, tumor grade, and lymph node status. Such individual prognostic parameters have been developed into the tumor, node and metastasis staging system [5] and Nottingham prognostic index [6,7]. In addition to this, various biomarkers (immunohistochemical markers) such as estrogen receptor alpha $(E R \alpha)$, progesterone receptor (PR), and the human epidermal growth factor receptor 2 (HER2) also represent mandatory elements for treatment $[8,9]$.

The biomarker-based treatment implements learning points for lower resource settings. First, it involves successful delivery mandates technical and analytical consistency, as incorrect profiling of basic parameters is profoundly detrimental. This has been governed by authoritative guidance from the American Society of Clinical Oncology (ASCO) and College of American Pathologists [8,9] and quality assurance by the United Kingdom National External Quality Assessment Service [10]. Second, despite novel biomarkers, indices and signatures, few have clinical utility. So according to this, guidance for reporting of tumor marker studies [11] and a tumor marker utility grading system (ASCO) has been published [12,13]. Third, the international availability of biomarkers remains very uneven and confounded by inferences from developed health-care systems than specific evaluation in lower resource settings. BRCA1 is the leading mutation leading to breast cancer [14].

Determining the ER, PR, and HER2/neu receptor status in breast cancer becomes medical practice nowadays. Clinical trials have shown the survival advantage for patients with hormone receptor positive status by treatment with adjuvant hormonal or chemotherapeutic regimens [15].

In normal cells, this gene is involved in DNA repair, transcription regulation, and tumor suppression. To prevent cancer, it has been studied that diets rich in phytochemicals can reduce the risk of cancer by $20 \%$. Plant natural product (phytoconstituent) has played an active role in generating a significant number of drug compounds in drug discovery program. Secondary metabolites and their derivatives from plants and other natural resources have been used for the treatment of various diseases [16].

In this review, established and emerging biomarkers, screening methods and various phytoconstituents were considered with reference to biological significance, clinical utility and resource implications.

\section{CANCER BIOMARKER}

"A cancer biomarker refers to a substance or process that is indicative of the presence of cancer in the body. A biomarker may be a molecule secreted by a tumor or a specific response of the body to the presence of cancer. It might be used to view how great that body response on medicine for an infection alternately condition. In addition, it is also called as an atomic marker [17]." Biomarkers about malignant might incorporate an expansive range from claiming biochemical entities, for example, nucleic acids, proteins, sugars, lipids, also little metabolites, cytogenetic also cytokinetic parameters and also entire malignant units discovered in the body liquid. A thorough understanding of the significance of every biomarker will be a chance to extremely critical not best for diagnosing the ailment reliably, as well as help in the decision of different restorative plan at present accessible that is liable will profit the patients [18]. Biomarkers are utilized within three elementary ways as a diagnostic tool, prognostic tool, and predictive tool [19]. 
Predictive carcinogenic biomarkers involve mutations in genes such as KRAS, p53, epidermal growth factor receptor, erbB2 for colorectal, liver, and pancreatic cancer; mutations in genes such as BRCA1, BRCA2 in breast, and ovarian cancer; abnormal methylation for malignant genes p16, CDKN2B, and p14ARF for forebrain cancer; hypermethylation for MYOD1, CDH1, and also CDH13 in cervical cancer; also hypermethylation of p16, p14, and RB1 for oral carcinoma [20].

Other illustrations of biomarkers [21]:

- Carcinogenic suppressors lost over malignancy. Examples: BRCA1 and BRCA2

- $\quad$ RNA. Examples: mRNA and microRNA

- Proteins found previously, figure liquids or tissue. Examples: Prostate-specific antigen, furthermore CA-125

\section{SCREENING METHODS}

Breast malignancy screening will be the restorative screening for asymptomatic, clearly solid ladies to breast malignancy previously, an endeavor to accomplish a sooner analysis. The supposition is that initial identification will enhance results. An amount for screening tests have been employed, including clinical and breast exams, mammography, hereditary screening, ultrasound, and furthermore attractive reverberation imaging [22].

\section{Mammogram}

A mammogram will be the proposed system for breast malignancy screening for those normal hazard populace. It will be that main screening modality demonstrated to decrease breast malignancy mortal sin. Time permits dangers to incorporate false negative outcomes also a false sense of security that might delay diagnosis; additional tests also tension connected with false sure comes about; and the truth that breast malignancy might be diagnosed for no change in the length or personal satisfaction about existence [23]. Higher the breast thickness will be connected with higher bosom disease danger previously, both premenopausal what's more postmenopausal ladies [24]. On the other hand, ladies for greatly low densities need to be as of late indicated to hold a fundamentally more awful prognosis regardless of patients' age, body mass index what's more menopausal status [25]. Breast malignancy was troublesome and it should be identified through mammograms did ladies for secondary breast thickness in light of practical malignancy thick breast tissues bring a comparable presence ahead of the mammillary body. Likewise a result, higher breast thickness is connected with a higher rate of false negatives (missed cancers) [26].

\section{Atomic breast imaging}

Atomic breast imaging is an atomic pharmaceutical system that is at present under investigation. It demonstrates guaranteeing effects for imaging skin for thick breast tissue furthermore might have accuracies tantamount to magnetic resonance imaging (MRI). It might be superior to a mammogram to some people with thick breast tissue, identifying 2 to 3 times more growth in this populace [27]. It, in any case, carries a more excellent danger about radiation harm making it improper to general breast malignancy screening [28]. It will be conceivable to decrease the measurement from claiming radiation utilized [29].

\section{Ultrasonography}

Therapeutic ultrasonic will be asymptomatic help with a mammogram. Including ultrasonic trying to ladies for thick breast tissue expands that identification from claiming breast cancer, as well as expands false [30]. There will be insufflated proof to help the utilization about ultrasonography to schedule screening in the normal danger populace. Ultrasonography ought not to be utilized likewise a solitary screening test. It might need a part likewise an assistant with mammogram previously, screening ladies for thick breasts, concerning illustration resolved toward a radiologist. Ultrasonography aides should recognize small, mammographically mysterious cancers; however, those generally sure predictive worth from claiming screening ultimo callous may be low.
Magnetic resonance imaging

Attractive reverberation imaging (MRI) need to be indicated will recognize growths not unmistakable ahead mammograms. Those Head quality for breast MRI may be its high negative predictive worth. A negative MRI could discount the vicinity of malignancy, and it will be a second degree for certainty, making it a phenomenal device around for screening in patients toward secondary hereditary danger alternately radiographically thick breasts, in pre-treatment arranging the place the degree of malady may be troublesome will determine through a mammogram. MRI might diagnose consider proliferative change, fibroadenomas, different normal discoveries in a glance, frequently eliminating those require to unreasonability and unnecessary biopsies alternately surgical methods. The spatial transient determination for breast MRI needs to be expanded for later years, making it could be allowed with recognizing alternately discount that vicinity for little in situ cancers, including ductal carcinoma in situ [31].

Signs for utilizing MRI to screening include solid family history about breast malignancy, patients with BRCA- 1 alternately BRCA- 2 oncogene mutations, assessment from claiming ladies for breast implants, historical backdrop from claiming past lumpectomy alternately breast biopsy surgeries, axillary metastasis for an obscure elementary carcinogenic, and exceptionally thick alternately scarred breast tissue [32]. MRI ought further bolstering not be utilized to screening the normal hazard populace. MRI might be utilized within particular condition likewise dictated toward a radiologist.

\section{BRCA ANALYSIS}

BRCA1 and BRCA2 mutations are the pre-eminent common cause of hereditary breast disease [33]. It was considered as human genes that produce tumor suppressor proteins, and it helps in repairing damaged DNA and play a role in ensuring the stability of the cell's genetic material. BRCA 1 and BRCA 2 mutations cause $20-25 \%$ of hereditary breast cancer [34] and 5-10\% of all breast cancers [35] and specific inherited mutations of these gene increases the risk of female breast and ovarian cancers, and they have been associated with increased risks of several additional types of cancer [36].

\section{BIOMARKER IN BREAST CANCER}

\section{Human epidermal growth factor-2}

HER-2 may be a paramount gene to subatomic focusing on medicine for breast malignant [37]. Determination of ER status about obtrusive breast carcinoma may be suitable as a prognostic and predictive figure, and ER+ predicts for a light of endocrine help for example, such that antiestrogen (tamoxifen) organization alternately ovarian concealment. Similarly, mankind's epidermal development component receptor 2 (HER2) positivity is handy for selecting focused on treatment with monoclonal immune response (trastuzumab) against HER2. Recently, microarray profiling from claiming obtrusive breast carcinoma need distinguished five different subtypes from claiming morphologically comparative breast malignancy (luminal A, luminal B, typical breast-like, HER2-overexpressing, furthermore the basal-like subtype), representing something like $15 \%$ for breast malignant situations furthermore portrayed toward cynicism for ER, PR, furthermore HER2, is connected with combative histology, poor prognosis, What's more lethargy of the ordinary endocrine therapies, shorter survival, and BRCA1-related breast malignancy $[38,39]$. Exactly breast malignancy needs a shelter amount for HER2 receptors. The additional HER2 receptors animate those malignancy units will separate What's more developed. When there would be higher levels of the HER2 protein done a breast cancer, it is known as HER2 certain breast malignant. The HER2/erbB2 gene, cell surface receptor tyrosine kinase is a pro-oncogene for signal transduction in cell development and division [40,41].

\section{Estrogens receptor}

Estrogens assume a huge part clinched alongside directing those development separation about normal, premalignant, harmful types, particularly breast epithelial cells, through interactional with 
two atomic ER (ER $\alpha$ or ERß) [42]. The ER is a capable predictive and prognostic marker, as well as a productive target to that medication from claiming hormone-dependent breast tumor for antiestrogens [43]. Estrogen impacts would exert through two sorts for particular receptor: ER $\alpha$ and ERß [44]. These atomic receptors would ligand-dependent interpretation elements that intercede those living impacts about estrogens and antiestrogens. Estrogen, 17ß-estradiol (E2), assumes a noticeable part to mediating the maturation, proliferation, differentiation, apoptosis, inflammation, metabolism, homeostasis, and impacts the growth and improvement about breast malignant. ERs act principally toward directing the outflow for target genes whose promoters hold numerous particular successions called estrogen-responsive component [45].

\section{Progesterone receptor}

Progesterone will be an intense breast mitogen. An essential capacity from claiming progesterone/PR will be should intercede the monstrous development of epithelial-derived mammary alveoli (amelogenesis association for alveoli under lobules) throughout puberty and pregnancy on preparation to lactation. PRs are ligand-activated interpretation element parts of the steroid hormone receptor (SR) subfamily. PRs capacity not just as basic controllers about interpretation as well as on initiate indicator transduction pathways, a number about which are included for pro-proliferative indicating in the breast [46-48].

\section{Cyclin D1}

Cyclin D1 is a right on time light of mitogenic incitement to a few cell types, yet the outcomes of the modified statement of this gene clinched alongside mankind's units about epithelial root stay undefined. We access the impacts for alterations for Cyclin D1 outflow in human breast malignant phones by generating T-47D units expressing mankind's Cyclin D1 under the control of a zinc-responsive metallothionein promoter [49]. The division also answers from claiming eukaryotic phones are intercede toward an arrangement of facilitated occasions that create a "cell cycle collins [50]." The cycle comprises a mitotic stage ( $M$ phase) an interim between succeeding mitoses (interphase). The $\mathrm{M}$ period is made from claiming both mitosis and cytokinesis. There are two fundamental aggregations for the cycle: G1/S cyclin that intercedes G1/S transition including Cyclin A, Cyclin D, and Cyclin E; and G2/M cyclin that controls progression from G2 to M phase, for example, Cyclin B [51]. D-type cyclins cooperation with CDK4 and CDK6 over promptly will work G1 phase, same time cycling prefers should CDK2 to late G1 phase [52]. Three D-type cyclins named Cyclin D1, D2, and D3, constantly on for which need aid prompted toward mitogens. Withdrawal the mitogens throughout G1 period makes fast debasement of D-type cyclin.

\section{Cyclin E}

Cyclin E will be a critical controller about cell cycle progression that together with the cyclin-dependent kinase (CDK) 2 may be vital for the G1, S move throughout those mammalian cell cycle [53,54]. It is a $50-\mathrm{kD}$ cycle protein, as well as up to five low-molecular-weight isoforms of cyclin. These isoforms, which need that aminic terminus, would hyperactive, concerning illustration compared with that full-length protein, in phosphorylating substrates prompting progression starting with that G1 stage of the S period. Cycline and their reactant CDK accomplices act positively to propel a cell through those proliferative cycle $[55,56]$. Actuation from claiming cyclin-CDK complexes brings about a course of protein phosphorylation that eventually actuate cell cycle progression.

\section{PHYTOCONSTITUENTS AGAINST BREAST CANCER}

- Characteristic plants have been used to prevent also will treat different illnesses for many a considerable length of time [57]. There are phenomenal wellsprings of bioactive segments exerting their wellbeing valuable effects, furthermore often, these wellsprings are materials for gourmet nourishment utilizations. Specific bioactive segments starting with the plants need to be affirmed to their anticancer exercises [58]. These incorporate curcumin starting with turmeric, genistein starting with soybean, tea pack polyphenols starting with green tea, resveratrol from grapes, sulforaphane starting with broccoli, isothiocyanates from cruciferous vegetables, silymarin from milk thistle, diallyl sulfisoxazole from garlic, lycopene starting with tomato, rosmarinine corrosive starting with rosemary, apigenin starting with parsley, and also gingerol from gingers [59].

- Apigenin, a flavone present in parsley, celery, chamomile [60] and Egyptian plant Moringa peregrine exhibits cytotoxic exercises against breast malignancy mobile lines (MCF 7), colon mobile transport (HCT 116) [61]. Apigenin needs to be been demonstrated will make a standout among the gainful mixes for different phases about carcinogenesis [62].

- Curcumin's anticancer impact is should actuate apoptosis over cancellous units without cytotoxic impacts looking into solid units [63]. Curcumin modulates development about carcinogenic phones through regulation of different mobile indicating pathways including cell burgeoning pathway (Cyclin D1, c-Myc) [64].

- Saffron is an zest from the bloom of the saffron crocus what's more an nourishment colorant exhibit in the dry stigmas of the plant Crocus sativus saffron. Furthermore, its ethanolic extracts would also be accounted for the investigations around human lung malignancy pancreatic carcinoma cell transport skin carcinoma colorectal carcinoma units and breast malignant. Crocetin influences the growth of malignancy phones by hindering nucleic corrosive synthesis, upgrading antioxidative system, promoting apoptosis also upsetting development component indicating pathways.

- Gingerol needs to be concentrated onto its anticarcinogenic impacts for those malignant done colon, pancreas, breast, and ovarian. Gingerol needs to be exhibited antioxidant, anti-inflammation, and antitumor pushing properties (declines inducible nitric oxide synthase) [65].

\section{CONCLUSION}

In this review, we aimed to overview the breast cancer biomarkers and their development. A biomarker is an objectively measured characteristic that can be evaluated as an indicator of normal biological response, pathogenic processes, or therapeutic responses. Various types of screening methods are clinical and breast exams, mammography, hereditary screening, ultrasound, and attractive reverberation imaging. Certain plants and its constituents have been playing a major role in decreasing the activity of biomarkers such as Her-2, ER, PR, Cyclin-D1, and Cyclin E. Breast cancer is a heterogeneous disease with vast differences between patients in regard to treatment response and prognosis. Hence, strategies for individualizing care are required.

"Keep your sunny side up, keep yourself beautiful, And indulge yourself !"

-Betsey Johnson.

\section{ACKNOWLEDGMENT}

With great pleasure, I express my gratitude to my project guide. She supported me in this endeavor and appreciated me in my efforts during my article. I would like to thank my coauthor for the effort and cooperation. Last but not the least, I would like to thank my friends for their constant source of inspiration.

\section{REFERENCES}

1. Elgadir AM, Salama M, Adam A. Anti-breast cancer from various natural sources, review. Int J Pharm Pharm Sci 2015;7(2):44-7.

2. Ferlay J, Shin HR, Bray F, Forman D, Mathers C, Parkin DM, et al. Cancer Incidence and Mortality Worldwide: IARC Cancer Base No. 10, Globocan. Vol. 2. Lyon, France: IARC; 2008.

3. Berry DA, Cronin KA, Plevritis SK, Fryback DG, Clarke L, Zelen M, et al. Effect of screening and adjuvant therapy on mortality from breast cancer. N Engl J Med 2005;353(17):1784-92.

4. Clarke M, Collins R, Darby S, Davies C, Evans V, Godwin J, et al. 
Effects of chemotherapy and hormonal therapy for early breast cancer on recurrence and 15-year survival: An overview of the randomised trials. Early Breast Cancer Trialists Collaborative Group. Lancet 2005;365:1687-17.

5. Sobin LH, Gospodarowicz MK, Wittekind C. TNM Classification of Malignant Tumours. $7^{\text {th }}$ ed. England, UK: Wiley-Blackwell; 2009.

6. Balslev I, Axelsson CK, Zedeler K, Rasmussen BB, Carstensen B, Mouridsen HT. The Nottingham prognostic Index applied to 9,149 patients from the studies of the Danish breast cancer cooperative group (DBCG). Breast Cancer Res Treat 1994;32(3):281-90.

7. D'Eredita G, Giardina C, Martellotta M, Haybitlle JL, Blamey RW, et al. Prognostic factors in breast cancer: The predictive value of the Nottingham prognostic index in patients with a long-term follow-up that were treated in a single institution. Eur J Cancer 2001;37:591-6.

8. Hammond ME, Hayes DF, Dowsett M, Allred DC, Hagerty KL, Badve S, et al. American society of clinical oncology/college of American pathologists guideline recommendations for immunohisto chemical testing of oestrogen and progesterone receptors in breast cancer. J Clin Oncol 2010;28:2784-95.

9. Wolff AC, Hammond ME, Schwartz JN, Hagerty KL, Allred DC, Cote RJ, et al. American society of clinical oncology/college of American pathologists guideline recommendations for human epidermal growth factor receptor 2 testing in breast cancer. J Clin Oncol 2007;25:118-45

10. Leake R, Barnes D, Pinder S, Ellis I, Anderson L, Anderson T, et al. Immunohistochemical detection of steroid receptors in breast cancer: A working protocol. UK Receptor Group, UK NEQAS, the Scottish breast cancer pathology group, and the receptor and biomarker study group of the EORTC. J Clin Pathol 2000;53(8):634-5.

11. McShane LM, Altman DG, Sauerbrei W, Taube SE, Gion M, Clark GM. Statistics subcommittee of the NCI-EORTC working group on cancer diagnostics. Reporting recommendations for Tumor marker prognostic studies. J Clin Oncol 2005;23(36):9067-2.

12. Hayes DF, Bast RC, Desch CE, Fritsche H Jr, Kemeny NE, Jessup JM, et al. Tumor marker utility grading system: A framework to evaluate clinical utility of Tumor markers. J Natl Cancer Inst 1996;88(20): 1456-6.

13. Harris L, Fritsche H, Mennel R, Norton L, Ravdin P, Taube S, et al. American society of clinical oncology 2007 update of recommendations for the use of Tumor markers in breast cancer. J Clin Oncol 2007;25(33):5287-312.

14. Iyer PM, Kumar PS, Karthikeyan S, Namboori PK. 'BRCA1' Responsiveness to wards breast cancer - A population-wise pharmacogenomics analysis. Int J Pharm Pharm Sci 2016;8(9):267-70.

15. Yadav R, Sen R, Chauhan P. ER, PR, HER2/NEU status and relation to clinic pathological factors in breast carcinoma. Int J Pharm Pharm Sci 2015;1(2):7.

16. Ramalingam S, Saravanan R, Brindha P. A review on the role of phytoconstituents in breast cancer cells. Int J PharmTech Res 2014;6(2): 799-808

17. Biomarker. NCI Dictionary of Cancer Terms. National Cancer Institute. Available from: https://www.cancer.gov/publications/dictionaries/ cancer-terms?cdrid $=45618$

18. Narayan BA, Rohit M, Abdullah F, Amit V, Dwarakanath BS. Cancer biomarkers: Current perspectives. Indian J Med Res 2010;132(2):129-49.

19. Biomarkers in Cancer: An Introductory Guide for Advocates 2013. p. 1-81.

20. Verma M, Manne U. Genetic and epigenetic biomarkers in cancer diagnosis and identifying high risk populations. Crit Rev Oncol Hematol 2006;60(1):9-18.

21. Mishra A, Verma M. Cancer biomarkers: Are we ready for the prime time? Cancers (Basel) 2010;2(1):190-208.

22. Kösters JP, Gøtzsche PC. Regular self-examination or clinical examination for early detection of breast cancer. Cochrane Database Syst Rev 2003;CD003373.

23. Breast Cancer Screening: Clinical Practice Guideline September, 2013. Available from: http://www.topalbertadoctors.org/download/243/ breast_cancer_guideline.pdf? 20170406230648.

24. Boyd NF, Martin LJ, Yaffe MJ, Minkin S. Mammographic density and breast cancer risk: Current understanding and future prospects. Breast Cancer Res 2011;13(6):223.

25. Masarwah A, Auvinen P, Sudah M, Rautiainen S, Sutela A, Pelkonen O, et al. Very low mammographic breast density predicts poorer outcome in patients with invasive breast cancer. Eur Radiol 2015;25(7):1875-82.

26. Houssami N, Kerlikowske K. The impact of breast density on breast cancer risk and breast screening. Curr Breast Cancer Rep 2012;4:161-8.

27. O'Connor M, Rhodes D, Hruska C. Molecular breast imaging. Expert
Rev Anticancer Ther 2009;9(8):1073-80

28. Moadel RM. Breast cancer imaging devices. Semin Nucl Med 2011;41(3):229-41

29. O'Connor MK, Li H, Rhodes DJ, Hruska CB, Clancy CB, Vetter RJ. Comparison of radiation exposure and associated radiation-induced cancer risks from mammography and molecular imaging of the breast. Med Phys 2010;37(12):6187-98.

30. Berg WA, Blume JD, Cormack JB, Mendelson EB, Lehrer D, Böhm-Vélez $\mathrm{M}$, et al. Combined screening with ultrasound and mammography vs mammography alone in women at elevated risk of breast cancer. J Am Med Assoc 2008;299(18):2151-63.

31. Hung JM, Sonnad SS, Schwartz JS, Langlotz CP. Accuracy of MR imaging in the work-up of suspicious breast lesions: A diagnostic metaanalysis. Acad Radiol 1999;6(7):387-97.

32. Nelson HD, Huffman LH, Fu R, Harris EL. Genetic risk assessment and BRCA mutation testing for breast and ovarian cancer susceptibility: Systematic evidence review for the U.S. preventive services task force. Ann Intern Med 2005;143(5);362-79.

33. Genetic Testing Facilities and Cost. Available from: http://www. breastcancer.org/symptoms/testing/genetic/facility cost.

34. Easton DF. How many more breast cancer predisposition genes are there? Breast Cancer Res 1999;1(1):14-7.

35. Campeau PM, Foulkes WD, Tischkowitz MD. Hereditary breast cancer: New genetic developments, new therapeutic avenues. Hum Genet 2008;124(1):31-42.

36. Pal T, Permuth-Wey J, Betts JA, Krischer JP, Fiorica J, Arango H, et al. BRCA1 and BRCA2 mutations account for a large proportion of ovarian carcinoma cases. Cancer 2005;104(12):2807-16.

37. Harris JR, Lippman ME, Morrow M, Osborne CK. Disease of the Breast. $3^{\text {rd }}$ ed. Philadelphia, PA: Lippincott Williams \& Wilkins; 2004. p. $620-52$.

38. Bauer R, Brown M, Cress RD, Parise C, Caggiano V. Descriptive analysis of estrogen receptor (ER)-negative, progesterone receptor (PR)-negative, and HER2-negative invasive breast cancer, the so-called triple-negative phenotype: A population-based study from the California cancer registry. Cancer 2007;109(9):1721-8.

39. Perou CM, Sørlie T, Eisen MB, van de Rijn M, Jeffrey SS, Rees CA, et al. Molecular portraits of human breast tumours. Nature 2000;406(6797):747-52

40. Heredia NJ, Belgrader P, Wang S, Koehler R, Regan J, Cosman AM, et al. Droplet digitalTM PCR quantitation of HER2 expression in FFPE breast cancer samples. Methods 2013:59(1):S20-3.

41. Shou J, Massarweh S, Osborne CK, Wakeling AE, Ali S, Weiss H, Schiff R. Mechanisms of tamoxifen resistance: Increased estrogen receptor-HER2/neu cross-talk in ER/HER2-positive breast cancer. J Natl Cancer Inst 2004;96(12):926-35.

42. Debeb1 YG, Berihu BA. Review on the role of estrogen receptors in breast cancer. Int J Pharm Sci Res 2015;6(8):1100-4.

43. Sommer S, Fuqua SA. Estrogen receptor and breast cancer. Semin Cancer Biol 2001;11(5):339-52.

44. Gustafsson JA. Estrogen receptor beta - A new dimension in estrogen mechanism of action. J Endocrinol 1999;163(3):379-83

45. McKenna NJ, Lanz RB, O’Malley BW. Nuclear receptor coregulators: Cellular and molecular biology. Endocr Rev 1999;20:321-44.

46. Migliaccio A, Piccolo D, Castoria G, Di Domenico M, Bilancio A, Lombardi $\mathrm{M}$, et al. Activation of the Src/p21 ras/Erk pathway by progesterone receptor via cross-talk with estrogen receptor. EMBO J 1998;17(7):2008-18.

47. Graham JD, Clarke CL. Physiological action of progesterone in target tissues. Endocr Rev 1997;18(4):502-19.

48. Daniel AR, Hagan CR, Lange CA. Progesterone receptor action: Defining a role in breast cancer. Expert Rev Endocrinol Metab 2011;6(3):359-69.

49. Musgrove EA, Lee CS, Buckley MF, Sutherland RL. Cyclin D1 induction in breast cancer cells shortens G1 and is sufficient for cells arrested in G1 to complete the cell cycle. Proc Natl Acad Sci U S A 1994:91:8022-6.

50. Collins K, Jacks T, Pavletich NP. The cell cycle and cancer. Proc Natl Acad Sci U S A 1997:94:2776-8.

51. Johnson DG, Walker CL. Cyclins and cell cycle checkpoints. Annu Rev Pharmacol Toxicol 1999;39:295-312.

52. Sherr CJ. Cancer cell cycles. Science 1996;274(5293):1672-7.

53. Keyomarsi K, Tucker SL, Buchholz TA, Callister M, Ding Y, Hortobagyi GN, et al. Cyclin E and survival in patients with breast cancer. N Engl J Med 2002;347(2):1566-75.

54. Gray-Babin J, Zalvide J, Fox MP, Knickerbocker CJ, DeCaprio JA, Keyomarsi K, et al. Cyclin E, a redundant cycling in breast cancer. Proc 
Natl Acad Sci 1996;93(26):15215-20.

55. Sherr CJ.G1 phase progression: Cycling on cue. Cell 1994;79(4);551-5.

56. Nasmyth K. Control of the yeast cell cycle by the Cdc 28 protein kinase. Curr Opin Cell Biol 1993;5(2):166-79.

57. Davies G. Time Tables of Medicine. New York: Black Dog \& Leventhal; 2000.

58. Gutheil WG, Reed G, Ray A, Dhar A. Crocetin: An agent derived from Saffron for prevention and therapy for cancer. Curr Pharm Biotechnol 2012;13(1):173-9.

59. Meeran SM, Ahmed A, Tollefsbol TO. Epigenetic targets of bioactive dietary components for cancer prevention and therapy. Clin Epigenetics 2010;1(3-4):101-16

60. Hoensch HP, Oertel R. Emerging role of bioflavonoids in gastroenterology: Especially their effects on intestinal neoplasia. World J Gastrointest Oncol 2011;3(5):71-4.

61. El-Alfy TS, Ezzat SM, Hegazy AK, Amer AM, Kamel GM. Isolation of biologically active constituents from Moringa peregrine (Forssk.) Fiori. (Family: Moringaceae) growing in Egypt. Pharmacogn Mag 2011;7(26):109-15.

62. Nicolas C, Sebastien F, Martinez MC. Anticancer properties of flavonoids: Roles in various stages of carcinogenesis. Cardiovasc Hematol Agents Med Chem 2011;9(2):62-77.

63. Bachmeier BE, Mohrenz IV, Mirisola V, Schleicher E, Romeo F et al. Curcumin down regulates the inflammatory cytokines CXCL1 and-2 in breast cancer cells via NFkappaB. Carcinogenesis 2008;29(4):779-89.

64. Ravindran J, Prasad S, Aggarwal BB. Curcumin and cancer cells: How many ways can curry kill tumor cells selectively? Am Assoc Pharm Sci J 2009;11(3):495-510.

65. Hu WE, Tin OK, Limin S, Zheng-Yuan S, Francisco F, Jong-Hun L, Ah-Ng TK. Plants against cancer: A review on natural phytochemicals in preventing and treating cancers and their drug ability. Anticancer Agents Med Chem 2012;12(10):1281-305. 